\title{
Analysis of the Influence of Economic Globalization and Informatization on the Development of China's Economics and Management Discipline
}

\author{
Suxin Huang \\ Nanchang Vocational University, Nanchang, Jiangxi,330500
}

Key words: economic globalization; informationization; economy and management; development; influence

\begin{abstract}
Economics and management disciplines as an applied discipline have always been the theoretical orientation of China's economic and social development. This is a discipline that can contribute greatly to society and is very conducive to China's economic and social development. At the same time, the disciplines of economics and management are constantly changing, and China's economic market is also developing dynamically. Therefore, China must grasp the characteristics of the development of the world economy and society at this stage, and the problems and opportunities that may be encountered in China's economic and social construction. Analyze so that you can face the challenges correctly. This paper focuses on the analysis of the impact of economic globalization and informatization on the development of China's economic and management disciplines.
\end{abstract}

\section{Economic Globalization and Informatization for China economic versus management Subject Development impact}

Because of economic globalization and informatization, both the times and the society have been further promoted in this context, and the coverage of global integration has become wider and wider, not only the economy, but also the cultural and political fields. Global integration is affected, and global integration can almost change the way people produce and consume. Economic globalization has also enabled the rapid circulation of goods and resources, and people have also gained a lot of convenience in the context of economic globalization. In the fields of finance and transportation in China, with the help of economic globalization, we have begun to break regional restrictions and become part of the global market operation system. China's economic development has also been affected by the development of the world economy, and it has prospered with the prosperity of the world economy. In recent years, foreign economies have also experienced difficulties in development and halted. This has already affected China's foreign trade, so the development of China's foreign trade is not as good as before. In the face of this situation, we should actively look for the cause of the problem and solve the problem as soon as possible so that China's economic market can develop well. My economy has been supported by investment for a long time, but because the country has not enough funds in recent years, the national economy is divided into two poles. The poor people cannot afford to buy basic daily consumer goods. People will not buy ordinary consumer goods. Therefore, this has also led to great intervention and influence in China's consumer goods market. In order to solve this problem, improve the status quo, and promote the development of China's consumer goods market, then we should study the economy and management in depth, because the economy and management can solve these problems well, but in the development of economic and management disciplines, It is clear that based on the development of China's economic market, it studies the development direction of economics and management disciplines and solves the problems caused by economic globalization and informationization.

\section{Strategies for the development of China's economic and management disciplines}

\subsection{Conducting localized academic research in economics and management disciplines}

At this stage, the study of China's economics and management disciplines is more and more in line with China's national conditions, but in the process of studying economics and management disciplines, it also involves many foreign research theories, then this requires researchers. Firstly, 
we will thoroughly understand the management theory and practice of foreign countries, and then obtain the part that can benefit the development of China's economic market, and through these parts that are conducive to the development of China's economic market, improve China's economic development system and help China solve it. Problems in the practice process. For the time being, researchers in China's economic management disciplines are mainly studying the relevant theories and practical results of foreign economic and management disciplines, in order to be able to obtain content that is conducive to China's economic construction. In-depth study of a content, build a relevant management system, and develop branches. However, in the development of relevant practical research in China, we cannot ignore the importance of theoretical research. Only by having sufficient understanding of economics and management disciplines can we help China promote the development of economic markets. Based on the advanced management of foreign countries, China can find a faster way to promote the economic and management disciplines to promote the development of China's economic market.

\subsection{Constructing a balanced economic and management discipline knowledge system}

In the disciplines of economics and management, there are still many sub-disciplines, and in order to strengthen the role of economics and management disciplines, researchers must conduct in-depth research on sub-disciplines in economics and management disciplines to build a more complete economic and management discipline. Knowledge System. First of all, establish a "college" consciousness, and incorporate all subjects involved in economic activities and management activities into the research field of economics and management disciplines, so that economic and management disciplines involve public, education, science and technology, military and other aspects. The structure of economics and management disciplines is very complex, so it is very difficult to link the branches of economics and management disciplines. Therefore, among economics and management disciplines, there should be no professional counterparts in economics and management. Researchers should also have researchers in other fields, such as education economics and management, and public economy and management. Through these researchers, China will be able to study the economic and management development path in line with China's characteristics. In addition, researchers in the economics and management disciplines should not only study the economy and management, but also study the branches of economics and management, and use the commonalities and intersections of these different disciplines to develop economic and management disciplines. It also promotes the development of China's economic market. At the same time, if the economics and management disciplines can be well developed, then our society can be better constructed.

\subsection{Cultivate an elite economic and management discipline research team}

In the context of economic globalization and informatization, China's economic and management disciplines want to be better developed, then we should first strengthen the study of China's economic and management disciplines, only in the economic and management disciplines have a clearer recognition After knowing, it is possible to cultivate relevant research talents based on the understanding of economics and management disciplines. Professional research talents can contribute to the development of China's economic society. But in order to create such a talent cultivation environment, first of all, talent planning and talent management should be carried out. Talent planning is crucial in it, because the talents related to economics and management disciplines fall into two categories, one is practical talents and the other is theoretical talents. If you want to plan for these two types of talents, you should strengthen the economy. Training with teachers in management disciplines to improve the quality of teachers in economics and management disciplines, so that these teachers can fully play their roles. However, at this stage, it is obvious that almost all of the economics and management discipline teachers graduate from this major, but even so, they cannot ignore the cultivation of talents of other professions. Only in this way can we improve the overall level of teachers and make a greater contribution to the cultivation of talents in China. In history, it has also been proved that many related researchers are also derived from other disciplines, so this also means that the collision between different disciplines has a very strong 
driving force for the development of China's economic and management disciplines.

\section{Conclusion}

In the context of economic globalization and informatization, China's economic and management disciplines will inevitably encounter development challenges, but China should not evade such challenges, but should carefully analyze the changes in the current market environment and identify the economy and The correct development direction of management disciplines, in-depth study of economics and management disciplines, construction of economic and management discipline knowledge systems, and the cultivation of relevant talents to promote the development of China's economic market, but also lay a solid foundation for the economic and management disciplines with distinctive characteristics in China.

\section{About the Author:}

Suxin Huang (July 1976-), male, Han nationality, Anhui Susong, Nanchang Vocational University, associate professor, master's degree, research direction: information and management.

\section{References}

[1] Foreign Marxists' Exploration and Argument about the Nature of Economic Globalization[j]. Zhao Shuce. Journal of Taiyuan Urban Vocational and Technical College. 2012(09)

[2] On Knowledge Economy and Economic Globalization[j]. Mao Jidong. Inner Mongolia Science and Technology and Economy. 2005(05)

[3] Reshaping the National Economic Function under Economic Globalization[j]. Yang Yanhong. Reform and Strategy. 2003(s1)

[4] Science and Technology: the Source of Economic Globalization[j]. Zhang Sai. Construction Enterprise Management. 2002(03)

[5] Economics about economic globalization[j]. Wang Xiaowen. Academic Monthly. 2001(01) 